Деревянко Наталія здобувач ступеня $\mathrm{PhD}$ кафедри вікової та педагогічної психології Рівненського державного гуманітарного університету ORCID iD: 0000-0001-6712-6474 DOI https://doi.org/10.35619/prap_rv.vi13.117

\title{
«ДОПОМОГА ІНШОМУ» ЯК СТРАТЕГІЯ ПРОСОЦІАЛЬНОГО РОЗВИТКУ ОСОБИСТОСТІ
}

Анотація. У статті визначено, щзо вибір типу поведінки особистості залежить від особистісних та сочіальних чинників. Охарактеризовано просоціальну поведінку як поведінку, щзо здійснюються з метою допомоги на користь соціальних спільнот та передбачає отримання користі допомагаючим, що відрізняє ії від альтруїстичної поведінки. Наведено форми просочіальної поведінки. Описано класифікації типів допомоги за різними параметрами (за Ільїним). Наведено характеристики типів допомоги: за складом тих, хто бере участь у допомозі (індивідуальна і групова), за часовим параметром (короткочасна (разова)) і довготривала (більш менш постійна, проявляється як турбота про когось), за змістом (матеріальна, фізична, інтелектуальна $i$ моральна). Зроблено висновки, щуо допомога іншому передбачає суб'єкт-суб'єктну взаємодію, і спрямована на покращення морального, матеріального, фізичного, інтелектуального становища того, хто потребує допомоги. Досліджено, що допомога іншому передбачає певний рівень мотивачї $i$ сукупність мотивів і потреб, які необхідно задовольнити допомагаючому. Визначено, щзо допомога іншому, передбачає двосторонню користь від допомоги, вона має статус засобу саморозвитку того, хто допомагає, у різних сферах залежно від мотивів його діяльності.

Ключові слова: просоціальність, стратегія,просоціальна поведінка, допомога іншому, розвиток особистості.

Постановка проблеми. У процесі взаємодії люди користуються різними поведінковими моделями. Однак, допомога іншим людям вважається однією 3 найважливіших людських якостей, і в той же час у науковому дискурсі $\epsilon$ найбільш дискусійною та малодослідженою стратегією просоціальної поведінки. Залишається й наразі відкритим питання чому люди допомагають один одному, якими мотивами вони керується, чи $є$ допомога взаємовигідною, чи є здатність до допомоги професійною якістю тощо. Особистісними детермінантами просоціальної поведінки часто називають соціальну відповідальність і емпатію, а також внутрішній локус контролю. Соціальна відповідальність i внутрішній локус контролю відповідають за формування у людини потреби допомогти іншим, в той час як емпатія сприяє розумінню людиною потреб інших і їх потреб (Eisenberg, 1986). Тому у психологічній літературі актуальним $є$ дослідження розуміння сутності допомагаючої дії, поведінки, а також потенціалу для особистісного розвитку людини у процесі допомоги.

Аналіз останніх досліджень і публікацій. Незважаючи на те, що термін «просоціальна поведінка» 3'явився з середини XX століття, нині у психології накопичено значну кількість праць з цієї проблеми. Просоціальну поведінку розглядали вітчизняні i зарубіжні дослідники, такі як Абульханова-Славська, Абраменкова, Адлер, Бендор, Братусь, Василюк, Вотсон, Кропоткін, Корчакова, Куницина, Леонтьєв, Маслоу, Павелків, Рубінштейн, Русалов, Ядов, Ялом та інші.

Дослідженням природи, сутності та особливостей допомоги займались психологи Ільїн, Молчанова, Наконечна, Киричук та ін. Однак накопичений досвід із зазначеної проблеми не вичерпує усіх аспектів, дослідження допомоги як стратегії просоціального розвитку особистості та потребує подальшого глибшого обгрунтування. 
Мета статті: здійснити теоретичний аналіз феномену «допомога іншому» як стратегії просоціального розвитку особистості. Відповідно до поставленої мети, варто вирішити наступні завдання: розкрити сутність понять «просоціальна поведінка», «допомога»; визначити види допомоги; висвітлити психологічні особливості «допомоги Іншому» як стратегії просоціального розвитку особистості.

Виклад основного матеріалу дослідження. Поведінка людини, іiї дії та вчинки безпосередньо визначаються рівнем розвитку нервової системи та психіки. У загальному людині притаманні різні типи поведінки: від інстинктивних до свідомих 3 відповідною ієрархією. Таким чином, опираючись на особистісті якості, систему цінностей, оточення кожна людина обирає у тій чи іншій ситуації певний тип поведінки. 3 цього приводу Молчанова зазначає, що вибір тієї або іншої стратегії поведінки (у тому числі допомагаючої) залежить від двох основних взаємопов'язаних чинників: розуміння або оцінки ситуації (контексту, в якому що-небудь відбувається); розуміння особи партнера з яким відбувається взаємодія. 3 одного боку, вирішення ситуації, тобто надання необхідної допомоги, залежатиме від змістовних характеристик особи (емпатії, здатності до ідентифікації, способів ухвалення рішення) і динамічних характеристик (спрямованості на надання допомоги, настрою, наявності/відсутності відповідальності), що більше співвідноситься з другим чинником. 3 іншого боку, просоціальна поведінка виступатиме як наслідування загальноприйнятих норм, громадських цінностей i думок, більшою мірою відповідає першому чиннику (Молчанова, 2013, с.4). Таким чином, вибір поведінки залежить від особистісних якостей та загальноприйнятих соціальних норм (допомагати, тому що «так прийнято», щоб не зазнати осуду суспільства). Розглянемо трактування феномену «просоціальна поведінка» у психологічному дискурсі.

За визначенням авторів монографії «Формування просоціальної поведінки учнів в умовах превентивного виховного середовища загальноосвітнього навчального закладу» просоціальна поведінка - це система дій та вчинків особистості, зумовлена свідомим прийняттям соціально значущих норм і цінностей, умінням конструктивно вирішувати міжособистісні та групові суперечності, несприйнятливістю до ризикованих способів полісуб'єктних взаємодій, здатністю до самореалізації у різних видах соціально значущої діяльності (2016). Просоціальна поведінка, за Ільїним, пов'язана 3 наданням допомоги (сприяння) в різних іiї проявах тому, хто іiі потребує, і за які не передбачається яких-небудь зовнішніх винагород. Таким чином, допомагаюча поведінка в перекладі на просту мову - це благодіяння, що проявляється в різних формах (підтримкою, турботою, співучастю, співчуттям i розумінням). Проте при допомагаючій поведінці можливі i особисті поневіряння. Деякі автори вважають, що допомагаюча поведінка на відміну від альтруїзму виключає які-небудь жертви власним інтересам. Але автор задає питання: хіба альтруїзм - не допомога? (Ільїн, 2013).

Термін «просоціальна поведінка» психологи використовують i для позначення моральних дій, що властиві певній культурі. Їх можна визначити як соціально-позитивні (Формування просоціальної, 2016). До широкого спектру форм просоціальної поведінки належать допомога, альтруїзм, співпраця, співчуття, поступливість, неагресивне відношення, ділення власним добром, дар, емпатія, щедрість, зацікавлення іншим, старанність, турботливість і ті всі типи діяльності, які спрямовані на покращення загального добробуту через зменшення соціальної несправедливості (Mussen, Eisenberg-Berg, 1977, с. 4).

У полі зору нашої уваги поняття «допомога іншому» як стратегія просоціального розвитку особистості. Тому, розглянемо поняття «допомога». Наконечна (2008) розглядає допомогу як взаємодію з людиною, що відбувається з метою «1) полегшення іiі страждання; 2) сприяння іï розвитку, розкриттю потенціалу її здібностей» (с. 84). За Ільїним, є два підходи до надання допомоги: той, що допомагає може або забезпечувати нужденну людину якиминебудь ресурсами, виконуючи замість нього роботу, або полегшувати іiі положення, надихаючи використовувати власні ресурси. Перший підхід пов'язаний з ситуацією, коли людина не справляється зі своїми проблемами тому, що їй бракує знань і умінь, щоб розв'язати проблему. Тому вона чекає допомоги від компетентнішої в цьому питанні людини. 
Другий підхід спрямований не на передачу готового безособового знання, а на активізацію внутрішніх ресурсів того, кому вона необхідна, щоб людина сама впоралась зі своїми проблемами. Існує декілька класифікацій видів допомоги, оскільки вона може бути класифікована за різними параметрами.

За часовим параметром допомога може бути короткочасною (разовою) i довготривалою (більш менш постійною, наприклад опікунство проявляється як турбота про когось) (Ільїн, 2013). Питання надання допомоги на довготривалій основі у психології вивчено менш ретельно, ніж питання, що стосуються спонтанної просоціальної поведінки. Так, Омото і Снайдер (1989). проводять порівняння спонтанної просоціальної поведінки і довготривалої, яка представлена волонтерством. На підставі проведеного порівняння, вони зробили припущення про те, що довготривалі форми надання допомоги визначаються диспозиційними особливостями того, хто допомагає.

За змістом допомога може бути матеріальною, фізичною, інтелектуальною i моральною. Матеріальна допомога полягає в наданні допомоги іншій людині за допомогою матеріальних засобів, таких як гроші або речі. Цей вид допомоги може бути реалізований в таких формах, як благодійність, пожертвування у вигляді одягу або інших матеріальних засобів. Цей вид допомоги вимагає від людини певного матеріального рівня добробуту та чіткої установки на надання допомоги безоплатно. Фізична допомога виражається у виконанні фізичних дій, спрямованих на надання підтримки людині. Фізична допомога може виявлятися в допомозі фізично недієздатним громадянам, надання допомоги в фізично важких видах діяльності і т. П. Специфікою цього виду допомоги $є$ iï практична направленість. Цей вид допомоги поширений в повсякденних справах. Прикладом такого виду допомоги $\epsilon$ волонтерська діяльність. Волонтерська діяльність - це добровільна діяльність, спрямована на надання безоплатних послуг людині або групі людей. Однією 3 волонтерських практик $є$ надання допомоги людям похилого віку в повсякденних завданнях, таких як похід в магазин, опіка та піклування над людьми похилого віку. Інтелектуальна допомога проявляється у виконанні інтелектуальної роботи для людини. Сюди можна включити надання допомоги з навчальними дисциплінами, допомога за допомогою поради, допомога під час прийняття рішень. Цей вид допомоги вимагає наявності певного рівня розвитку когнітивних здібностей. Прикладом такого виду допомоги може бути репетиторство на благодійній основі. Моральна допомога є наданням емоційної підтримки людині. Вона може полягати в наданні турботи, розради, переконанні. Цей вид допомоги схильний поліпшити емоційний стан людини, сприяє зниженню ії переживань. Для надання даного виду допомоги, людині часто потрібні здібності до емпатії, оскільки ій необхідно зрозуміти ситуацію і переживання людини, яка потребує допомоги. Як правило, даний вид допомоги вимагає від людини хорошого розуміння особистості іншого і реалізується в процесі бесіди (Ільїн, 2013).

Наконечна (2009) розглядаючи допомогу іншому як суб'єкт-суб'єктну взаємодію визначила такі ії характеристики: вона сутнісно пов'язана зі сприянням входженню іншого в стан суб'єктності; допомога іншому сприяє розкриттю потенціалу суб'єктності учасників взаємодії; вона пов'язана особистісними переживаннями; має інтегративний характер; $\epsilon$ складною соціопсихологічною реальністю. Кирильчук (2018) опрацьовуючи теоретичні положення допомоги іншому, визначив, що цей феномен має інтеракційну природу. Автор зазначає, що у взаємодії людини з навколишнім світом задіяні як зовнішні, так і внутрішні умови, які взаємопов'язані в єдину мотиваційну систему (бажання, потреба, цілі допомоги тощо), які в індивідуальній історії розвитку людини складаються в іiі стиль життя. Психологічний зміст допомоги іншому полягає у сприянні виведенню цього іншого в позицію суб'єктності, що передбачає певні зміни особливостей обох суб'єктів взаємодії, а саме - активності, рефлексивності, емпатичності та креативності, а також відповідного змісту і рівня мотивації. 3 огляду на це, допомагаюча дія водночас має зміст і статус психологічного засобу саморозвитку особистості, що надає допомогу. Допомога іншому - це особлива діяльність співпереживання, рефлексивного вислуховування, емпатичної кооперації між двома індивідами, один з яких перебуває в скрутному становищі і потребує 
допомоги. В результаті їх взаємодії особистість, що потребувала допомоги, стає більш благополучною, а допомагаючий суб’єкт - більш зрілим, відповідальним, повноцінно функціонуючим.

Висновки та перспективи досліджень. Аналіз наукових досліджень дозволяє зробити висновки, вибір типу поведінки особистості залежить від особистісних та соціальних чинників. Просоціальна поведінка - це поведінка, що здійснюються 3 метою допомоги на користь соціальних спільнот. Ця поведінка також передбачає отримання користі допомагаючим, що відрізняє iі від альтруїстичної поведінки. До широкого спектру форм (типів) просоціальної поведінки належать допомога, альтруїзм, співпраця, співчуття, поступливість, неагресивне відношення, ділення власним добром, дар, емпатія, щедрість, зацікавлення іншим, старанність, турботливість і та діяльність, що спрямована на покращення загального добробуту через зменшення соціальної несправедливості до відношенню до іншого. Щодо класифікацій допомоги, то вона може бути розрізнена за за різними параметрами.

Допомога іншому передбачає суб'єкт-суб'єктну взаємодію, і спрямована на покращення морального, матеріального, фізичного, інтелектуального становища того, хто потребує допомоги. Допомога іншому передбачає певний рівень мотивації і сукупність мотивів і потреб, які необхідно задовольнити допомагаючому. Тобто, допомога іншому, зважаючи на традиційне трактування допомоги, передбачає двосторонню користь від допомоги. Допомога іншому має статус засобу саморозвитку того, хто допомагає, у різних сферах залежно від мотивів його діяльності. Перспективою подальших досліджень у цьому напрямі вважаємо відбір та обгрунтування психодіагностичного інструментарію стратегії просоціальної поведінки «допомога Іншому» підлітків в умовах інклюзивного навчання.

\section{СПИСОК ПОСИЛАНЬ}

Ильин, Е. (2013). Психология помощчи. Альтруизм, эгоизм, эмпатия. Взято с https://psy.wikireading.ru/13256.

Кириченко, В. І., Єжова, О. О., Нечерда, В. Б., Тарасова, Т. В., Хомич, О. Л. (2016). Формування просочіальної поведінки учнів в умовах превентивного виховного середовища загальноосвітнього навчального закладу. Тернопіль: ТзОВ "Терно-граф".

Киричук, О. (2018). Мотивація допомоги іншому й стильова організація життя особистості. Психологічні перспективи, 32, 123-134.

Молчанова, Н. В. (2013). Просоциальное поведение как условие межкультурного взаимодействия. Известия Саратовского университета. Новая серия. Серия Акмеология образования. Психология развития, 2, 1(5).

Наконечна, М. М. (2008). Психологічні аспекти формування схильності допомагати іншому. Актуальні проблеми психологї̈, 10, 6 (2), 84-87.

Наконечна, М. М. (2009). Допомога іншому як психологічний засіб розвитку особистості. (Автореф. дис. канд. психол. наук). Київ.

Наконечна, М. М. (2014). Допомога іншому як суб'єкт-суб'єктна взаємодія. Взято $з$ http://www.ndu.edu.ua/images/stories/2014/konf_psy/nakonechna.pdf

Eisenberg, N. (1986). Altruistic emotion, cognition, and behaviour. Hillsdale, NJ: Lawrence Erlbaum.

\section{REFERENCES}

Il'in, E. (2013). Psihologija pomoshhi. Al'truizm, jegoizm, jempatija [Assistance Psychology. Altruism, selfishness, empathy]. Vzjato s https://psy.wikireading.ru/13256. [in Russian].

Kirichenko, V. I., Ezhova, O. O., Necherda, V. B., Tarasova, T. V., \& Khomich, O. L. (2016). Formuvannia prosotsialnoi povedinky uchniv $v$ umovakh preventyvnoho vykhovnoho seredovyshcha zahalnoosvitnoho navchalnoho zakladu [Formation of prosocial behavior of students in the conditions of preventive educational environment of a comprehensive educational institution]. Ternopil. TzOV "Terno-Count". [in Ukrainian]. 
Kyrychuk, O. (2018). Motyvatsiia dopomohy inshomu y stylova orhanizatsiia zhyttia osobystosti [The motivation to help others and the stylistic organization of a person's life]. Psykholohichni perspektyvy, 32, 123-134. [in Ukrainian].

Molchanova, N. V. (2013) Prosocial'noe povedenie kak uslovie mezhkul'turnogo vzaimodejstvija [Prosocial behavior as a condition of intercultural interaction]. Izvestiya Saratovskogo universiteta. Novaja seriya. Seriya Akmeologija obrazovanija. Psihologija razvitija, 2, 1 (5). [in Russian].

Nakonechna, M. M. (2008). Psykholohichni aspekty formuvannia skhylnosti dopomahaty inshomu [Psychological aspects of forming a tendency to help another]. Aktualni problemy psykholohii, 10, 6 (2), 84-87. [in Ukrainian].

Nakonechna, M. M. (2009). Dopomoha inshomu yak psykholohichnyi zasib rozvytku osobystosti [Helping others as a psychological means of personal development]. (Avtoref. dys. kand. psykhol. nauk). Kyiv. [in Ukrainian].

Nakonechna, M. M. (2014). Dopomoha inshomu yak subiekt-subiektna vzaiemodiia [Helping others as a subject-subjective interaction]. Vziato $\mathrm{z}$ http://www.ndu.edu.ua/ images/stories/2014/konf_psy/nakonechna.pdf. [in Ukrainian].

Eisenberg, N. (1986). Altruistic emotion, cognition, and behavior. Hillsdale, NJ: Lawrence Erlbaum. [in English].

\title{
ASSISTANCE TO ANOTHER AS A PROSOCIAL PERSONAL DEVELOPMENT STRATEGY
}

Natalia Derevyanko

PhD student ,

Department of Lifespan \& Pedagogical Psychology

Rivne State University of the Humanities

ORCID iD: 0000-0001-6712-6474

DOI https://doi.org/10.35619/prap_rv.vi13.117

\begin{abstract}
The article determines that the choice of the type of personality behavior depends on personal and social factors. Prosocial behavior is characterized as behavior that is intended to help the benefit of social communities and involves the benefit of helping people, which distinguishes it from altruistic behavior. The forms of prosocial behavior are given. A wide variety of forms (types) of prosocial behavior include assistance, altruism, cooperation, compassion, condescension, non-aggressive attitude, sharing of one's own good, gift, empathy, generosity, interest in others, diligence, caring and and activities aimed at improving the common good reduction of social injustice in relation to another. Classifications of types of assistance according to different parameters (by E. Ilyin) are described. It can be individual and group, short-term (onetime) and long-term, and in content - material, physical, intellectual and moral. It has been concluded that helping others involves subject-subjective interaction and is aimed at improving the moral, material, physical, and intellectual position of the person in need of assistance. It has been researched that helping others implies a certain level of motivation and a set of motives and needs that need to be met by the helping person.

That is, assisting the other, given the traditional treatment of assistance, implies a bilateral benefit from the assistance. Assistance to another has the status of a self-development tool for the assisting person in various fields, depending on the motives of his activity. The prospect of further research in this area is the selection and justification of the psychodiagnostic toolkit of the strategy of prosocial behavior "Helping others" adolescents in inclusive learning.
\end{abstract}

Key words: prosociality, strategy, prosocial behavior, helping others, personal development. 